\title{
Soils of Thotapalli Major Irrigation Project of North-Coastal Andhra Pradesh: Characterization and Classification
}

\author{
K. Himabindu, P. Gurumurthy* and P.R.K. Prasad \\ Department of Soil Science and Agricultural Chemistry, Agricultural College, \\ Bapatla-522101, Andhra Pradesh, India.
}

\begin{abstract}
Six representative pedons from Devarapalli $\left(\mathrm{P}_{1}\right)$, Gujjangivalasa $\left(\mathrm{P}_{2}\right)$, Patikivalasa $\left(\mathrm{P}_{3}\right)$, Gangada $\left(\mathrm{P}_{4}\right)$, Aamiti $\left(\mathrm{P}_{5}\right)$ and Maddivalasa $\left(\mathrm{P}_{6}\right)$ villages belonging to ayacut of Thotapalli major irrigation project of North-Coastal Andhra Pradesh were studied. Pedons 1, 2 and 5 were developed from granite-gneiss, while pedons 3 , 4 and 6 had their parent legacy with granite-gneiss mixed with calcareous murrum. The soils of $\mathrm{P}_{1}$ and $\mathrm{P}_{2}$ were moderately deep to very deep having argillic horizon while cambic sub-surface diagnostic horizon was noticed in $\mathrm{P}_{3}, \mathrm{P}_{4}$ and $\mathrm{P}_{5}$. Deep and wide surface cracks and slickensides close enough to intersect were observed in $\mathrm{P}_{4}$ and $\mathrm{P}_{6}$. The pedons $\mathrm{P}_{1}, \mathrm{P}_{2}, \mathrm{P}_{3}$ and $\mathrm{P}_{5}$ had sandy loam to sandy clay loam texure and it was clay loam to clay in cultivated plains $\left(\mathrm{P}_{4}\right.$ and $\left.\mathrm{P}_{6}\right)$. The soils were low to medium in organic carbon content. The CEC ranged from 6.4 to $32.5 \mathrm{cmol}(\mathrm{p}+) \mathrm{kg}^{-1}$ and the soil exchange complex was dominated by calcium followed by magnesium, sodium and potassium. The ratio of CEC/ clay was low in $\mathrm{P}_{2}$ medium in $\mathrm{P}_{1}, \mathrm{P}_{3}$ and $\mathrm{P}_{5}$ and high in $\mathrm{P}_{4}$. Devararapalli pedon was classified as Typic Haplustalfs, Gujjangivalasa as Typic Haplustults, Patikivalasa and Amiti as Typic Haplustepts, Gangada as Vertic Haplustepts and Maddivalas as Chromic Haplusterts.
\end{abstract}

Keywords: Soil characterization, classification, argillic horizon, cambic horizon, Vertisol, Inceptisol

\section{Introduction}

The knowledge of soils with respect to their extent, distribution, characteristics and potential use are important for optimising land use. The study of soils today has assumed an increased importance due to rapidly declining land area under agriculture, declining soil fertility and increasing soil degradation through unbridled population increase, urbanisation, improper land use policies and irrational use of inputs (Kanwar 2004). It is always required to create soil database on any ayacut area of proposed irrigation project which is lacking for Srikakulam and Vizianagaram district under Thotapalli reservoir to maximise. The irrigation use efficiency for sustainable crop production and hence present investigation was carried out.

*Corresponding author (Email: peddintigurumurthy@gmail.com)

\section{Materials and Methods}

The study area comprises parts of Srikakulam and Vizianagaram districts of north coastal region of Andhra Pradesh under Thotapalli reservoir. It is located between $18^{\circ} 12^{\prime}$ to $18^{\circ} 33^{\prime} \mathrm{N}$ latitude and $83^{\circ} 29^{\prime}$ to $83^{\circ} 38^{\prime}$ E longitude. The location map of the area and site of representative pedons is presented in figure 1 . The geology of the area is granite-gneiss with calcareous murrum (Table 1). The climate is semi-arid to sub-humid monsoonic type. The mean annual temperature and rainfall were $28.34{ }^{\circ} \mathrm{C}, 950.8 \mathrm{~mm}$ and $26.48{ }^{\circ} \mathrm{C}$, $1108.7 \mathrm{~mm}$ in Vizianagaram and Srikakulam districts, respectively. The soil moisture is ustic and soil temperature regime is iso-hyperthermic. The natural vegetation in the area comprises of Borasus 
falabellifera, Azadirachata indica, Cocas nucifera, Palmyrah spp, Cyprus spp, Cynodon spp, Euphorbia spp, Tridax procumbens, Calotropis spp, Lucas spp. and Typhaspp.

Reconnaissance soil survey was conducted in the ayacut area of Thotapalli major irrigation canal during April to June, 2018 using Survey of India toposheets of 1: 50,000 scale as per the procedure outlined by AIS\&LUS (1970). Auger bores, mini pits,

Table 1. Soil-site characteristics of different pedons road cuts and 15 pedons located on uplands and plains were studied for their morphological properties. Six representative pedons were included in the present study (Table 2). Horizon-wise samples were collected and processed following standard procedures. These pedons were classified according to Soil Survey Staff (2014). Land capability classification up to subclass level was done based on limitations and potentials of soils (Klingebiel and Montgometry 1966) and land use plans were suggested.

\begin{tabular}{|c|c|c|c|c|c|c|c|}
\hline Pedon & $\begin{array}{l}\text { Profile } \\
\text { location }\end{array}$ & Mandal & District & $\begin{array}{l}\text { Slope } \\
\%\end{array}$ & $\begin{array}{l}\text { Physio- } \\
\text { graphy }\end{array}$ & Drainage & $\begin{array}{l}\text { Parent } \\
\text { material }\end{array}$ \\
\hline $\mathrm{P}_{1}$ & Devarapalli & Ranastalam & Srikakulam & $1-3$ & Uplands & $\begin{array}{l}\text { Moderate } \\
\text { to well } \\
\text { drained }\end{array}$ & Granite-gneiss \\
\hline $\mathrm{P}_{2}$ & $\begin{array}{l}\text { Gujjangi- } \\
\text { valasa }\end{array}$ & Gurla & Vizianagaram & $1-3$ & Uplands & $\begin{array}{l}\text { well } \\
\text { drained }\end{array}$ & Granite-gneiss \\
\hline $\mathrm{P}_{3}$ & $\begin{array}{l}\text { Patikava- } \\
\text { lasa }\end{array}$ & $\begin{array}{l}\text { Cheepuru- } \\
\text { palli }\end{array}$ & Vizianagaram & $1-3$ & Uplands & $\begin{array}{l}\text { Moderate } \\
\text { to well } \\
\text { drained }\end{array}$ & $\begin{array}{l}\text { Granite-gneiss } \\
\text { mixed with } \\
\text { calcareous } \\
\text { murrum }\end{array}$ \\
\hline $\mathrm{P}_{4}$ & Gangada & Balijipeta & Vizianagaram & $0-1$ & Plains & $\begin{array}{l}\text { Poorly } \\
\text { drained }\end{array}$ & $\begin{array}{l}\text { Granite-gneiss } \\
\text { mixed with } \\
\text { calcareous } \\
\text { murrum }\end{array}$ \\
\hline $\mathrm{P}_{5}$ & Amity & Therlam & Vizianagaram & $1-3$ & Uplands & $\begin{array}{l}\text { Moderate } \\
\text { to well } \\
\text { drained }\end{array}$ & Granite-gneiss \\
\hline $\mathrm{P}_{6}$ & $\begin{array}{l}\text { Maddiva- } \\
\text { lasa }\end{array}$ & Vangara & Srikakulam & $0-1$ & Plains & $\begin{array}{l}\text { Poorly } \\
\text { drained }\end{array}$ & $\begin{array}{l}\text { Granite-gneiss } \\
\text { mixed with } \\
\text { calcarious } \\
\text { murrum }\end{array}$ \\
\hline
\end{tabular}

\section{Results and Discussion}

Soil morphology

Pedon $\mathrm{P}_{1}, \mathrm{P}_{2}$ and $\mathrm{P}_{6}$ are more than $120 \mathrm{~cm}$ deep while $P_{3}$ and $P_{4}$ had calcareous murrum after $90 \mathrm{~cm}$. Hard gravel layer was found after $80 \mathrm{~cm}$ in $\mathrm{P}_{5}$. These pedons had their colour in 10YR but in lower horizon colour was in 7.5 YR or 5YR. The Pedons $\mathrm{P}_{1}, \mathrm{P}_{4}, \mathrm{P}_{5}$ and $\mathrm{P}_{6}$ had variable texture ranging from coarse to fine with depth while $\mathrm{P}_{2}$ and $\mathrm{P}_{3}$ exhibited uniform texture throughout the profile. These variations are due to nature of parent material, in situ weathering, and translocation of clay and age of soils (Geethasireesha and Naidu 2013). Pedons $\mathrm{P}_{1}$ and $\mathrm{P}_{2}$ had granular structure at surface and sub-angular blocky in lower layers. Pedons $\mathrm{P}_{4}$ and $\mathrm{P}_{6}$ had angular blocky to blocky structure. Pedon $\mathrm{P}_{3}$ and $\mathrm{P}_{5}$ exhibited sub-angular blocky structure throughout the profile. The variation in structural development could be due to movement of clay and soluble material to lower layers as well as over burden pressure.

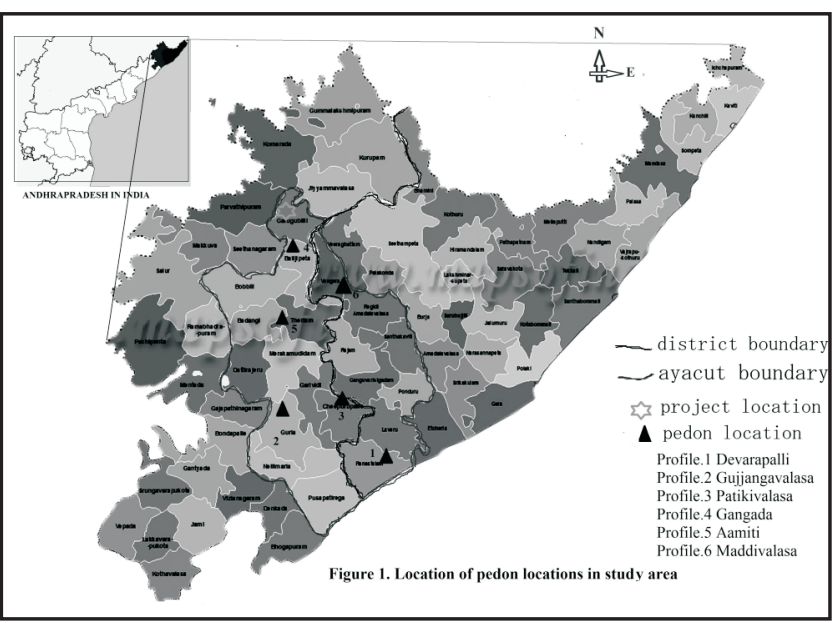




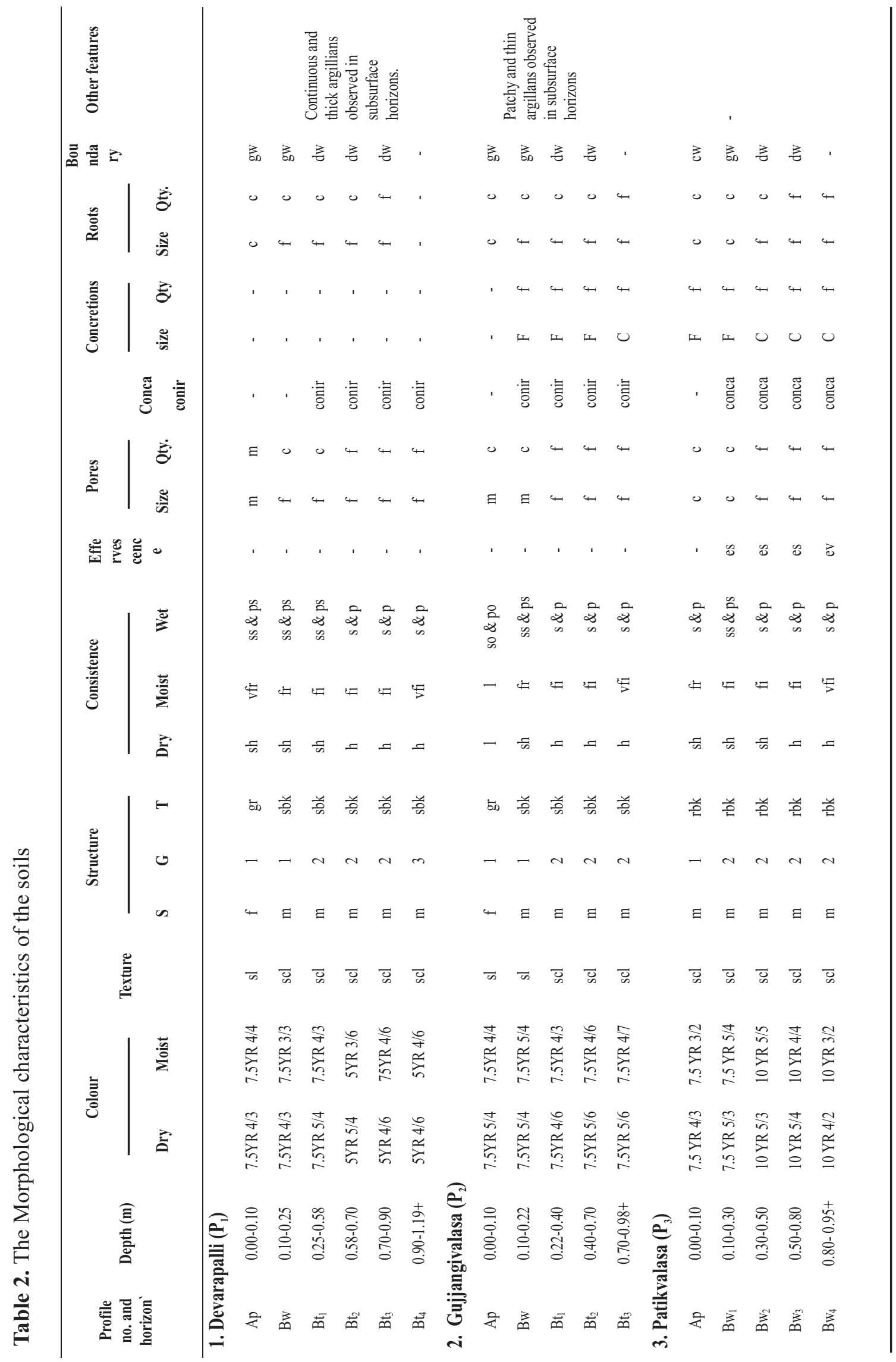




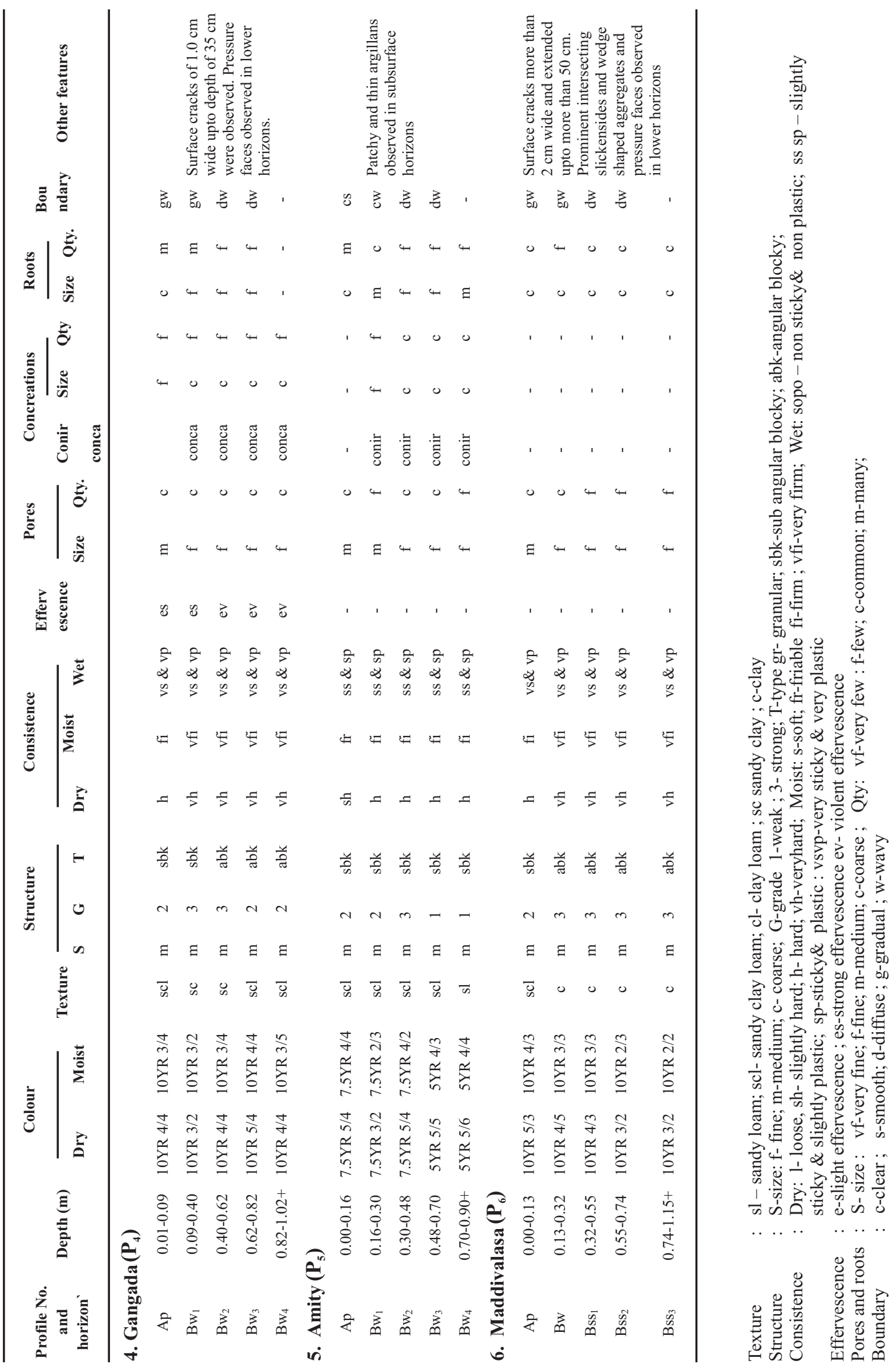


Physico-chemical properties

The clay content in the soil ranged from 12.6 to 45.2 per cent (Table 3) and increased with depth, which might be due to translocation of clay from surface to sub-surface horizons with percolating water in coarse textured soils $\left(\mathrm{P}_{1}, \mathrm{P}_{2}, \mathrm{P}_{3}, \mathrm{P}_{5}\right)$ and intense chemical weathering in sub-surface layers of fine textured soils $\left(\mathrm{P}_{4}, \mathrm{P}_{6}\right)$. These findings are in accordance with the results reported by Sreedharreddy and Naidu (2016). The sand content in different horizons of the pedons varied from 37.3 to 76.5 per cent. In general, the sand content decreased with depth except in $\mathrm{P}_{3}$, wherein it did not follow any trend of distribution with depth. Pedon $\mathrm{P}_{1}, \mathrm{P}_{2}$, $\mathrm{P}_{3}$ had relatively higher sand content owing to intense physical weathering. The silt content varied from 10.9 to 18.9 per cent and it showed irregular trend of distribution with depth.

Table 3. Physical and physico-chemical properties of soils

\begin{tabular}{|c|c|c|c|c|c|c|c|c|c|c|c|c|c|c|c|}
\hline \multirow{3}{*}{$\begin{array}{c}\text { Profile } \\
\text { No. \& } \\
\text { horizon }\end{array}$} & \multirow{3}{*}{$\begin{array}{l}\text { Depth } \\
\text { (m) }\end{array}$} & \multirow{3}{*}{$\begin{array}{c}\text { Gravel } \\
(\%)\end{array}$} & \multirow{3}{*}{$\begin{array}{c}\text { Sand } \\
(\%)\end{array}$} & \multirow{3}{*}{$\begin{array}{l}\text { Silt } \\
(\%)\end{array}$} & \multirow{3}{*}{$\begin{array}{l}\text { Clay } \\
(\%)\end{array}$} & \multirow{3}{*}{ pH } & \multirow{3}{*}{$\begin{array}{c}\text { E.C } \\
\left(\mathrm{dSm}^{-1}\right)\end{array}$} & \multirow{3}{*}{$\begin{array}{c}\text { Organic } \\
\text { carbon } \\
(\%)\end{array}$} & \multirow{3}{*}{$\begin{array}{c}\mathrm{CaCO}_{3} \\
(\%)\end{array}$} & \multirow{3}{*}{ CEC } & \multicolumn{4}{|c|}{ Exchangeable bases } & \multirow{3}{*}{$\begin{array}{c}\text { Base } \\
\text { saturation } \\
(\%)\end{array}$} \\
\hline & & & & & & & & & & & $\mathrm{Ca}^{2+}$ & $\mathbf{M g}^{2+}$ & $\mathrm{Na}^{+}$ & $\mathbf{K}^{+}$ & \\
\hline & & & & & & & & & & & \multicolumn{4}{|c|}{$\mathrm{cmol}\left(\mathrm{p}^{+}\right) \mathrm{kg}^{-1}$ soil } & \\
\hline \multicolumn{16}{|c|}{$\mathbf{P}_{1}:$ Devarapalli } \\
\hline Ap & $0.00-0.10$ & 4.5 & 62.2 & 18.6 & 19.2 & 6.23 & 0.13 & 0.534 & - & 13.50 & 3.96 & 1.02 & 0.28 & 0.04 & 39.26 \\
\hline $\mathrm{Bw}$ & $0.10-0.25$ & 3.1 & 58.0 & 17.5 & 24.5 & 6.61 & 0.17 & 0.301 & - & 15.40 & 5.85 & 0.67 & 0.35 & 0.07 & 45.06 \\
\hline Bt1 & $0.25-0.58$ & 4.0 & 53.5 & 17.5 & 29.0 & 7.34 & 0.17 & 0.231 & - & 17.00 & 6.01 & 1.05 & 0.63 & 0.11 & 45.88 \\
\hline Bt2 & $0.58-0.70$ & 2.3 & 56.0 & 16.0 & 28.0 & 7.41 & 0.21 & 0.215 & - & 15.40 & 5.90 & 1.00 & 0.24 & 0.09 & 46.95 \\
\hline Bt3 & $0.70-0.90$ & 2.3 & 60.5 & 15.5 & 24.0 & 7.35 & 0.23 & 0.220 & - & 14.20 & 5.76 & 0.52 & 0.22 & 0.08 & 46.34 \\
\hline Bt4 & $0.90-1.19+$ & 3.0 & 58.0 & 17.0 & 25.0 & 7.48 & 0.23 & 0.205 & - & 14.20 & 5.72 & 0.60 & 0.21 & 0.10 & 46.69 \\
\hline \multicolumn{16}{|c|}{$P_{2}:$ Gujjangivalasa } \\
\hline Ap & $0.00-0.10$ & 5.0 & 76.5 & 10.9 & 12.6 & 4.87 & 0.11 & 0.376 & - & 6.40 & 0.88 & 0.22 & 0.10 & 0.06 & 23.33 \\
\hline $\mathrm{A} 2$ & $0.10-0.22$ & 5.1 & 68.0 & 14.8 & 17.2 & 5.43 & 0.13 & 0.256 & - & 7.10 & 1.25 & 0.36 & 0.13 & 0.08 & 25.63 \\
\hline Bt1 & $0.22-0.40$ & 6.9 & 69.1 & 10.4 & 20.5 & 5.51 & 0.15 & 0.250 & - & 9.63 & 1.75 & 0.45 & 0.11 & 0.05 & 24.51 \\
\hline Bt2 & $0.40-0.70$ & 6.9 & 67.8 & 11.0 & 21.2 & 5.96 & 0.20 & 0.135 & - & 8.15 & 1.57 & 0.42 & 0.10 & 0.06 & 26.38 \\
\hline Bt3 & $0.70-0.98+$ & 19.1 & 68.0 & 11.5 & 20.5 & 5.50 & 0.26 & 0.123 & - & 8.15 & 1.72 & 0.48 & 0.14 & 0.05 & 29.33 \\
\hline \multicolumn{16}{|c|}{$\mathbf{P}_{3}:$ Patikavalasa } \\
\hline Ap & $0.00-0.10$ & 5.43 & 61.3 & 14.4 & 24.3 & 7.23 & 0.19 & 0.330 & 1.3 & 15.30 & 8.35 & 1.05 & 0.25 & 0.10 & 63.73 \\
\hline Bw1 & $0.10-0.30$ & 5.64 & 60.5 & 13.0 & 26.5 & 7.48 & 0.20 & 0.226 & 3.4 & 17.20 & 8.86 & 1.01 & 0.72 & 0.12 & 62.27 \\
\hline Bw2 & $0.30-0.50$ & 5.13 & 58.2 & 16.1 & 25.7 & 7.54 & 0.22 & 0.196 & 3.0 & 14.20 & 7.36 & 1.31 & 0.28 & 0.09 & 63.66 \\
\hline Bw3 & $0.50-0.80$ & 6.01 & 59.9 & 13.6 & 26.5 & 7.91 & 0.23 & 0.180 & 7.0 & 11.70 & 6.90 & 1.22 & 0.33 & 0.06 & 72.74 \\
\hline Bw4 & $0.80-0.95+$ & 8.03 & 63.2 & 12.5 & 24.3 & 8.28 & 0.31 & 0.135 & 9.5 & 13.50 & 8.23 & 1.38 & 0.41 & 0.03 & 74.44 \\
\hline \multicolumn{16}{|c|}{$P_{4}:$ Gangada } \\
\hline Ap & 0.00-0.09 & 5.1 & 55.2 & 15.8 & 29.1 & 7.88 & 0.39 & 0.450 & 3.15 & 27.35 & 20.80 & 2.18 & 0.71 & 0.13 & 87.09 \\
\hline Bw1 & $0.09-0.40$ & 5.6 & 51.0 & 14.1 & 34.9 & 8.04 & 0.43 & 0.316 & 6.30 & 31.80 & 24.70 & 2.24 & 0.80 & 0.11 & 87.58 \\
\hline Bw2 & $0.40-0.62$ & 6.3 & 48.1 & 15.0 & 36.9 & 8.26 & 0.44 & 0.291 & 7.10 & 29.50 & 20.30 & 3.82 & 1.17 & 0.09 & 86.03 \\
\hline Bw3 & $0.62-0.82$ & 7.1 & 53.4 & 13.2 & 33.4 & 8.50 & 0.47 & 0.253 & 9.8 & 30.10 & 20.20 & 3.50 & 1.19 & 0.13 & 83.12 \\
\hline Bw4 & $0.82-.02+$ & 21.5 & 54.3 & 14.1 & 31.6 & 8.71 & 0.58 & 0.213 & 13.8 & 28.80 & 20.50 & 3.61 & 1.18 & 0.15 & 88.33 \\
\hline \multicolumn{16}{|c|}{$P_{5}:$ Amiti } \\
\hline Ap & $0.00-0.16$ & 5.1 & 65.3 & 13.7 & 21.0 & 6.53 & 0.24 & 0.520 & & 16.80 & 4.83 & 1.12 & 0.35 & 0.14 & 38.33 \\
\hline $\mathrm{A} 2$ & $0.16-0.30$ & 5.6 & 63.2 & 13.6 & 23.2 & 7.20 & 0.26 & 0.376 & - & 14.90 & 4.83 & 1.61 & 0.32 & 0.17 & 44.60 \\
\hline Bw2 & $0.30-0.48$ & 6.3 & 58.1 & 16.6 & 25.3 & 7.61 & 0.31 & 0.226 & - & 14.90 & 4.10 & 1.50 & 0.48 & 0.09 & 42.40 \\
\hline Bw3 & $0.48-0.70$ & 7.1 & 56.4 & 18.4 & 25.2 & 7.14 & 0.39 & 0.110 & 1.1 & 16.10 & 4.10 & 1.80 & 0.52 & 0.08 & 40.37 \\
\hline Bw4 & $0.70-0.90+$ & 26.3 & 61.4 & 15.0 & 23.6 & 7.10 & 0.45 & 0.110 & 1.35 & 15.25 & 4.28 & 1.48 & 0.16 & 0.02 & 39.61 \\
\hline \multicolumn{16}{|c|}{$P_{6}:$ Maddivalasa } \\
\hline Ap & $0.00-0.13$ & 0.8 & 43.0 & 18.9 & 38.1 & 7.80 & 0.48 & 0.619 & - & 29.10 & 18.90 & 2.18 & 0.50 & 0.10 & 74.50 \\
\hline $\mathrm{Bw}$ & $0.13-0.32$ & 0.8 & 41.5 & 17.0 & 41.5 & 8.16 & 0.56 & 0.302 & 1.1 & 32.50 & 20.10 & 3.04 & 1.32 & 0.18 & 75.82 \\
\hline Bss1 & $0.32-0.55$ & 0.4 & 39.0 & 17.0 & 44.0 & 8.12 & 0.45 & 0.231 & 1.1 & 32.50 & 20.00 & 3.35 & 1.25 & 0.12 & 76.06 \\
\hline Bss2 & $0.55-0.74$ & 0.5 & 39.0 & 18.9 & 42.1 & 8.04 & 0.53 & 0.110 & 1.5 & 28.90 & 19.80 & 3.25 & 1.15 & 0.12 & 84.15 \\
\hline Bss3 & $0.74-1.15+$ & 1.1 & 37.3 & 17.5 & 45.2 & 7.91 & 0.60 & 0.110 & 2.9 & 31.10 & 21.60 & 3.46 & 1.05 & 0.10 & 84.28 \\
\hline
\end{tabular}


Pedons $\mathrm{P}_{3}, \mathrm{P}_{4}, \mathrm{P}_{6}$ were slightly alkaline to alkaline; $\mathrm{P}_{2}$ had acid $\mathrm{pH}$ while $\mathrm{P}_{1}$ and $\mathrm{P}_{5}$ were neutral. The $\mathrm{pH}$ of these pedons increased with depth which could be due to continuous removal of basic cations by crop plants and/or leaching of basic cations to deeper layers along with percolating water and as release of organic acids in surface layers during decomposition of organic matter. The $\mathrm{pH}$ of $\mathrm{P} 3, \mathrm{P}_{4}$ and $\mathrm{P}_{6}$ are in consonance with $\mathrm{CaCO}_{3}$ Content (Visalakshidevi et al. 2015). These pedons were non-saline. The organic carbon in different horizons of the pedons ranged from 0.11 to 0.62 per cent and decreased with depth, which could be due to enriched surface horizon with crop residue, left over roots mass and farm yard manure application. Calcium carbonate ranged from 1.3 to 9.5 per cent in $\mathrm{P}_{3}, 3.15$ to 13.8 in $\mathrm{P}_{4}$ and in general increased with depth in all the pedons. The increase in calcium carbonate content could be attributed to the leaching of bicarbonate from upper layer during rainy season and their subsequent precipitation as carbonate in the lower layer (Leelavathi et al. 2009). The cation exchange capacity varied from 5.40 to $32.5 \mathrm{cmol}\left(\mathrm{p}^{+}\right) \mathrm{kg}^{-1}$ soil and it was irregularly distributed with depth. Pedons $\mathrm{P}_{4}$ and $\mathrm{P}_{6}$ recorded higher CEC due to high clay content and expanding nature of clay. The exchangeable complex of the soils was dominated by $\mathrm{Ca}^{+2}$. Exchangeable sodium was relatively higher in $\mathrm{P}_{4}$ and $\mathrm{P}_{6}$.

\section{Soil classification}

Pedons $\mathrm{P}_{3}, \mathrm{P}_{4}$ and $\mathrm{P}_{5}$ with cambic subsurface diagnostic horizon were classified as Inceptisols at order level and Ustepts at suborder level owing to ustic soil moisture regime. At greatgroup level these three pedons were classified as Haplustepts. At subgroup level pedon $\mathrm{P}_{3}$ and $\mathrm{P}_{5}$ were classified as Typic Haplustepts due to absence of lithic contact within $50 \mathrm{~cm}$ from surface. However, pedon $\mathrm{P}_{4}$ was classified at subgroup level as
Vertic Haplustepts due to presence of surface cracks of more than $5.0 \mathrm{~mm}$ wide within $125 \mathrm{~cm}$ and presence of wedge shaped aggregates in sub surface.

Pedon $\mathrm{P}_{1}$ was classified as Alfisol at order level due to the presence of argillic sub-surface diagnostic horizon with more than 35 per cent base saturation. At suborder level it was placed under Ustalf owing to Ustic soil moisture regime. At greatgroup level, it was classified as Haplustalf. At subgroup level the pedon was classified as Typic Haplustalf.

Pedon $\mathrm{P}_{2}$ was grouped to the order Ultisol because of presence of argillic sub-surface diagnostic horizon with less than 35 per cent base saturation and low active clay (low ratio of CEC/clay). At suborder level these soils were placed in Ustults due to ustic soil moisture regime. At greatgroup, this pedon was grouped as Haplustult and Typic Haplustult at sub group level with fine-loamy textural family class

Pedon $\mathrm{P}_{6}$ was classified as Vertisol at order level because of more than 30 per cent clay, more than $25 \mathrm{~cm}$ thick slickenside zone with in $100 \mathrm{~cm}$. At greatgroup level, the pedon was grouped as Haplusterts since it does not have properties of salic, gypsic or calcic horizon with in $100 \mathrm{~cm}$ depth. At sub group level it was classified as Chromic Haplustert because of the colour value moist were 4 in surface horizon. At family level the pedon was placed under fine textural family class with smectitic mineralogy.

\section{Land capability classification}

The grouping of soils into capability classes and subclasses is done mainly based on the severity of limitations viz., erosion risk, wetness limitation, soil limitation, slope and climate limitation. These limitations can be improved by the addition of organic manures, addition of tank silt, providing drainage facilities, soil fertility management, adopting irrigation methods etc. 
Himabindu et.al

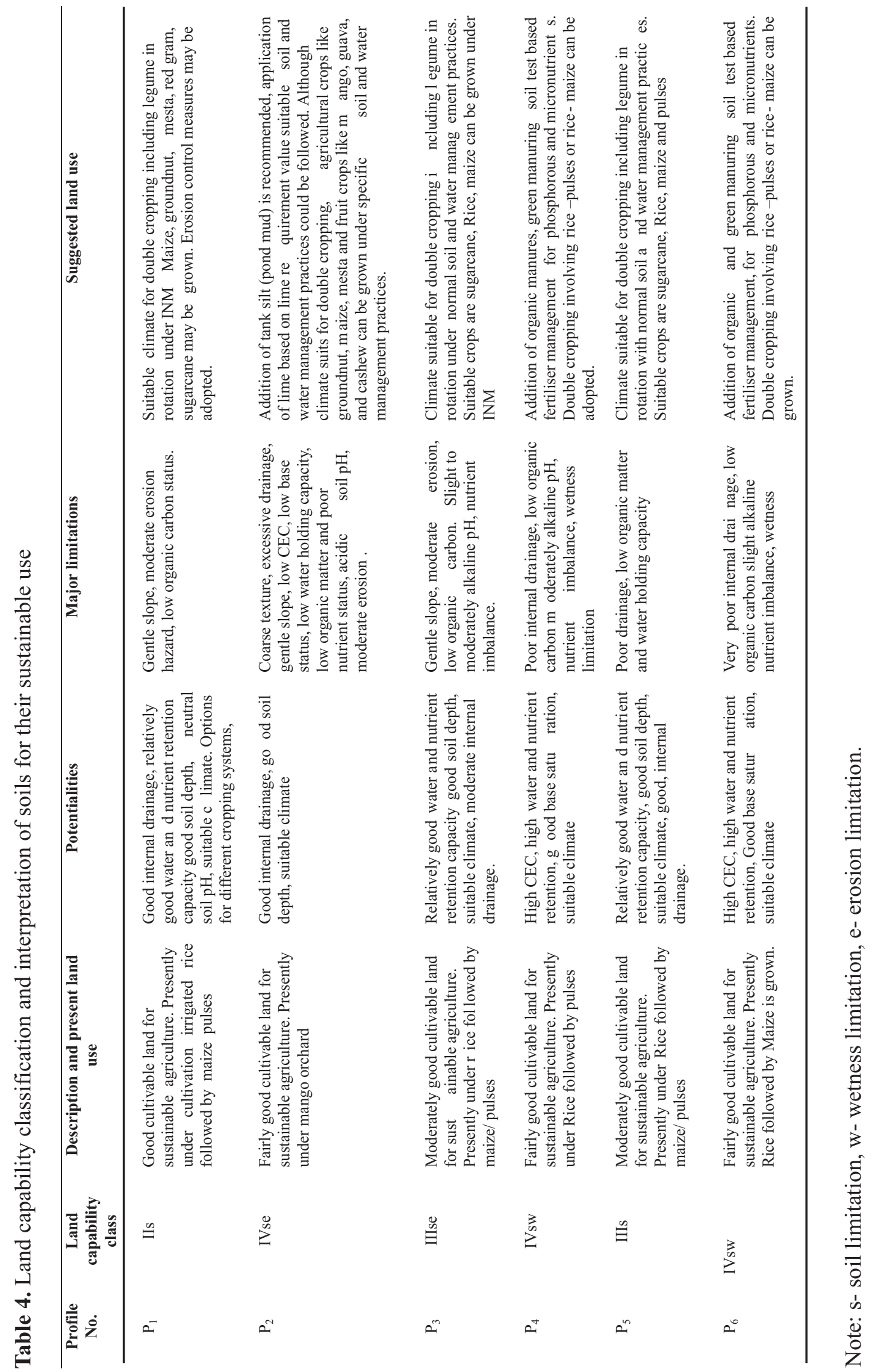




\section{Acknowledgement}

The authors thank Acahrya N.G. Ranga Agricultural University for providing financial support and infrastructural facilities for the study.

\section{References}

AIS\&LUS (1970). Soil Survey Manual, All India Soil and Land Use Survey organisation, IARI, New Delhi, pp.1-63

Geethasireesha, P.V., and Naidu, M.V.S. (2013). Studies on genesis, characterization, and classification of soils in semi-arid agro-ecological region: A case study in Banaganapalle mandal of Kurnool district in Andhra Pradesh. Journal of the Indian Society of Soil Science 61, 167-178.

Kanwar, J.S. (2004). Address by the guest of honour, $69^{\text {th }}$ annual convention of the Indian Society of Soil Science held at the Acharya N.G Ranga Agricultural University, Hyderabad. Journal of the Indian Society of Soil Science 52, 295-296.
Klingebiel A.A and Montgomery P.R. (1966). Land Capability Classification, Agriculture Handbook 210, Soil Conservation Service, USDA. Washington, D.C.

Leelavathi, G.P., Naidu, M.V.S., Ramavatharam, N., and Karunasagar, G. (2009). Studies on genesis, classification and evaluation of soils for sustainable land use planning in Yerpedu mandal of Chittoor district, Andhra Pradesh. Journal of the Indian Society of Soil Science 57, 109-120.

Soil Survey Staff(2014).'Keys to soil Taxonomy, $12^{\text {th }}$ Edition. (USDA/NRCS. Washington, D.C.)

Sreedharreddy, K., and Naidu, M.V.S. (2016). Characterization and classification of soils in semi-arid region of Chennur mandal in Kadapa district, Andhra Pradesh. Journal of the Indian Society of Soil Science 64, 207-217.

Vishalakshidevi, P.A., Naidu, M.V.S., and Ramakrishnarao, A. (2015). Characterization and classification of sugarcane growing soils in central and eastern mandals of Chittor district in Andhra Pradesh. Current Advances in Agricultural Sciences 7, 41-48.

Received: December, 2017 Accepted: April, 2018 